\title{
ANALISIS FAKTOR YANG MEMPENGARUHI TINGKAT PENGANGGURAN DI KOTA TARAKAN
}

\section{ANALYSIS OF FACTORS AFFECTING THE UNEMPLOYMENT LEVEL IN TARAKAN CITY}

\author{
Hasbi $^{1)}$, Pither Palungan ${ }^{2)}$ \\ (Universitas Borneo Tarakan)
}

Abstrak: Tujuan penelitian ini adalah untuk mengetahui pengaruh upah, inflasi, pertumbuhan ekonomi dan pertumbuhan penduduk terhadapa tingkat penganguran di Kota Tarakan selama priode 2007-2016. Dengan data yang di peroleh dari Dinas Ketenagakerjaan dan perindustria, Badan Pusat Statistik (BPS) Kota Tarakan. Permasalahan yang diangkat dalam penulisan ini adalah Analisis Mengenai upah, inflasi, pertumbuhan ekonomi dan pertumbuhan penduduk apakah berpengaruh terhadap tingkat Pengangguran di Kota Tarakan secara Parsial dan simultan. Tujuan dari penelitian ini adalah untuk mengetahui seberapa besar pengaruh upah, inflasi, pertumbuhan ekonomi dan pertumbuhan penduduk terhadap tingkat pengangguran di Kota Tarakan secara Parsial dan simultan. Alat analisis yang digunakan dalam penelitian ini adalah Analisis Regresi Linear Berganda dengan bantuan Program Statistical Package Forsocial Sciense (SPSS) Versi 16.0 Hasil penelitian secara parsial bahwa tingkat upah, inflasi, pertumbuhan ekonomi dan pertumbuhan penduduk berpengaruh signifikan terhadapa tingkat pengagguran di Kota tarakan. Sedangkan hasil dari penelitian secara simultan hanya variabel upah yang berpengaruh signifikan terhadap tingkat pengagguran di Kota Tarakan, sedangkan variabel inflasi, perumbuhan ekonomi dan pertumbuhan penduduk tidak berpengaruh signifikan terhadapa tingkat pengangguran di Kota Tarakan. Di mana koefisiensi regresi upah terhadap tingkat pengagguran 49,68\% koefisiensi regresi inflasi terhadap tingkat pengagguran 3,3\%, koefisiensi regresi pertumbuhan ekonomi terhadap tingkat pengagguran 21,6\% dan koefisiensi regresi pertumbuhan ekonomi terhadap tingkat pengagguran 11,6\%.

Kata Kunci : Upah, Inflasi, Pertumbuhan Ekonomi, Pertumbuhan Penduduk, Tingkat pengangguran

Abstract: The purpose of this study is the effect of wages, inflation, economic growth and population growth on the level of unemployment in the city of Tarakan during the period 2007-2016. With the data obtained from the Manpower and Industry Agency, the Tarakan City Central Statistics Agency (BPS). The issues raised in this writing are Analysis of wages, inflation, economic growth and population growth whether it affects the unemployment rate in Tarakan City in Partial and Simultaneous. The purpose of this study was to determine how much influence wages, inflation, economic growth and population growth on the City of Tarakan in Partial and simultaneous. The analytical tool used in this study is Multiple Linear Regression Analysis with the help of the Statistical Package Forsocial Sciense (SPSS) Version 16.0 The results of the study are part of the level of wages, inflation, economic growth and population growth have a significant effect on the level of unemployment in the city of Tarakan. While the results of a simultaneous study of variables have a significant effect on the level of unemployment in Tarakan City, while the variables of 
inflation, economic growth and population growth have no significant effect on the unemployment rate in Tarakan City. Where wage regression coefficient on unemployment rate is $49.68 \%$ inflation regression coefficient on unemployment rate of $3.3 \%$, regression coefficient of economic growth on unemployment rate of $21.6 \%$ and regression coefficient of economic growth to unemployment rate of $11.6 \%$.

Keywords: Wage, Inflation, Economic Growth, Population Growth, Unemployment Rate

\section{LATAR BELAKANG}

Indonesia sebagai negara berkembang masih belum bisa terlepas dari berbagai masalah mulai dari kemiskinan, pengangguran hingga ke sektor lain tak terkecuali pada masalah ketenagakerjaan. Pengangguran yang semakin bertambah jumlahnya merupakan masalah yang rumit dan lebih serius dari masalah perubahan dalam distribusi pendapatan yang kurang menguntungkan penduduk yang berpendapatan rendah. Keadaan di negara berkembang dalam beberapa dasawarsa ini menunjukkan bahwa pembangunan ekonomi tidak sanggup menciptakan kesempatan kerja yang lebih cepat dari pertambahan penduduk.

Bertambahnya jumlah penduduk akan selalu diwarnai dengan munculnya masalah-masalah akibat kehidupan penduduk yang dinamis. Pertumbuhan penduduk yang tinggi serta meningkatnya kegiatan di beberapa sektor menimbulkan berbagai masalah di wilayah-wilayah perkotaan misalnya permasalahan yang umum terjadi di Indonesia. Seperti yang telah dikemukakan oleh banyak pakar mengenai studi kota, bahwa penduduk akan bertempat tinggal di kota dan kawasan sekitar kota. Hal ini didasarkan bahwa jumlah penduduk kota di dunia mempunyai kecenderungan makin besar dan tidak terkecuali pada Kota Tarakan.

Kota Tarakan adalah kota yang tumbuh cepat secara alamiah baik di lihat dari jumlah penduduknya maupun dari kemampuan ekonominya yang berdampak pada pemenuhan sarana dan prasana. Secara umum, tingkat pengangguran Kota Tarakan dalam beberapa tahun mengalami penurunan, namun Kota Tarakan belum dapat mengungguli empat Kabupaten di kawasan Provinsi Kalimantan Utara, Kabupaten Malinau, Kabupaten Tana

Tidung, Kabupaten Bulungan, Kabupaten Nunukan. Tingkat pengangguran Kota Tarakan adalah berada di urutan pertama di Provinsi Kalimantan Utara dengan jumlah 5.841 jiwa, Kabupaten Bulungan di urutan kedua dengan jumlah 3.941 jiwa, Kabupaten Malinau di urutan ketiga dengan jumlah 3.220 jiwa, Kabupaten Nunukan urutan ke empat dengan jumlah 2.834 jiwa dan Kabupaten Tana Tidung di urutan paling akhir dengan jumlah 243 jiwa. (Kalimantan Utara dalam angka 2017).

\section{RUMUSAN MASALAH}

Berdasarkan latar belakang tersebut maka rumusan masalah yang akan diteliti adalah:

1. Apakah upah, inflasi, pertumbuhan ekonomi dan pertumbuhan penduduk, berpengaruh terhadap tingkat pengangguran di Kota Tarakan secara parsial ?

2. 2. Apakah upah, inflasi, pertumbuhan ekonomi dan pertumbuhan penduduk, berpengaruh terhadap tingkat pengangguran di Kota Tarakan secara simultan? 


\section{TUJUAN PENELITIAN}

Berdasarkan latar belakang dan rumusan masalah di atas, maka tujuan penelitian ini adalah:

1. Tujuan penelitian ini bertujuan untuk mengetahui dan menganalisis seberapa besar pengaruh upah, inflasi, pertumbuhan ekonomi dan pertumbuhan penduduk terhadap tingkat pengangguran di Kota Tarakan secara parsial.

2. Tujuan penelitian ini bertujuan untuk mengetahui dan menganalisis seberapa besar pengaruh upah, inflasi, pertumbuhan ekonomi dan pertumbuhan penduduk terhadap tingkat pengangguran di Kota Tarakan secara simultan.

\section{TINJAUAN PUSTAKA}

\section{$\underline{\text { Penduduk }}$}

Penduduk adalah orang-orang yang berada di dalam suatu wilayah yang terikat oleh aturan-aturan yang berlaku dan saling berinteraksi satu sama lain secara terus menerus. Dalam sosiologi, penduduk adalah kumpulan manusia yang menempati wilayah geografi dan ruang tertentu. Masalahmasalah kependudukan dipelajari dalam ilmu demografi penduduk atau warga suatu daerah didefinisikaan menjadi dua

1. Orang yang tinggal di daerah tersebut.

2. Orang yang secara hukum berhak tinggal di daerah tersebut. Dengan kata lain orang yang mempunyai surat resmi untuk tinggal di daerah tersebut. Misalkan bukti kewarganegaraan, tetapi memilih tinggal di daerah lain (Said, 1995).

\section{$\underline{\text { Pertumbuhan Penduduk }}$}

Pertumbuhan penduduk adalah perubahan jumlah penduduk di suatu wilayah tertentu pada waktu tertentu dibandingkan waktu sebelumnya. Semakin maraknya pertumbuhan penduduk di suatu wilayah maka akan semakin banyak pula masyarakat yang menganggur atau yang tidak mempunyai pekerjaan karena lapangan kerja yang tercipta tidak memenuhi syarat untuk jumlah penduduk yang semakin bertambah tiap tahunnya (Sadono Sukirno,2005).

\section{Pertumbuhan Ekonomi}

Pertumbuhan ekonomi
wilayah adalah pertambahan
pendapatan masyarakat secara
keseluruhan yang terjadi di wilayah
tersebut, yaitu kenaikan seluruh nilai
tambah (added value) yang terjadi.
Perhitungan pendapatan wilayah pada awalnya dibuat dalam harga berlaku. Namun agar dapat melihat pertambahan dari satu kurun waktu ke kurun waktu berikutnya, harus dinyatakan dalam nilai riil, artinya dinyatakan dalam harga konstan. Biasanya BPS dalam menerbitkan laporan pendapatan regional tersedia angka dalam harga berlaku dan harga konstan. Menurut Boediono, pertumbuhan ekonomi adalah proses kenaikan output perkapita dalam jangka panjang. Jadi, persentase pertambahan output itu haruslah lebih tinggi dari presentase perambahan jumlah penduduk dan ada kecendrungan dalam jangka panjang bahwa pertumbuhan itu akan berlanjut. Menurut model pertumbuhan ekonomi HarrodDomar tentang teori pertumbuhan mantap (Steady Growth Theory) yang merupakan pengembangan analisis keynes, lebih menekankan pada peranan kunci perlunya penanaman modal dalam proses penciptaan 
pertumbuhan ekonomi (Tarigan, 2009).

\section{$\underline{\text { Inflasi }}$}

Inflasi adalah kecendrungan dari harga-harga untuk menaik secara menyeluruh dan terus menerus. Kenaikan harga dari satu atau dua barang saja tidak disebut inflasi, kecuali bila kenaikan tersebut meluas atau mengakibatkan kenaikan pada sebagian besar harga barang-barang lain yaitu harga makanan, minuman, rokok, dan tembakau, harga sandang, harga kesehatan, harga pendidikan, rekreasi, dan olahraga, harga transportasi, komunikasi, dan jasa keuangan. Dari definisi tersebut, ada tiga komponen yang harus dipenuhi agar dapat dikatakan terjadi inflasi (Boediono, 1999) yaitu :

1. Kenaikan harga, yaitu apabila harga suatu komoditas menjadi lebih tinggi dari harga periode sebelumnya.

2. Bersifat umum, yaitu kenaikan harga komoditas secara umum yang dikonsumsi masyarakat bukan merupakan kenaikan suatu komoditas yang tidak menyebabkan harga naik secara umum.

3. Berlangsung terus menerus, kenaikan harga yang bersifat umum juga belum akanmemunculkan inflasi, jika terjadi sesaat misalnya kenaikan harga pada saat lebaran atau tahun baru bukan merupakan inflasi.

$\underline{\text { Upah }}$

Upah adalah suatu penerimaan sebagai imbalan dari pengusaha kepada karyawan untuk suatu pekerjaan atas jasa yang telah atau dilakukan dan dinyatakan atau dinilai suatu persetujuan atas peraturan perundang-undangan serta dibayarkan atas dasar suatu perjanjian kerja antara pengusaha dengan karyawan termasuk tunjangan, baik untuk karyawan itu sendiri maupun untuk keluarganya (Sumarsono, 2009:151).

Upah yang diberikan oleh pengusaha secara teoritis dianggap sebagai harga diri tenaga yang dikorbankan pekerja terhadap kepantingan produksi, sehubungan dengan hal itu maka upah yang diterima pekerja dapat dibedakan dua macam yaitu:

1. Upah Nominal, yaitu sejumlah upah yang dinyatakan dalam benuk uang yang diterima secara rutin oleh para pekerja.

2. Upah Rill adalah kemampuan upah nominal yang diterima oleh para pekerja jika di tukarkan dengan barang dan jasa, yang ditukur berdasarkan banyaknya barang dan jasa yang bisa didapatkan dari pertukaran tersebut.

\section{Pengangguran}

Pengertian penganguran menurut Badan Pusat Statistik (BPS) dalam indikator ketenagakerjaan, pengangguran adalah penduduk yang tidak bekerja namun sedang mencari pekerjaan atau sedang mempersiapkan suatu usaha baru atau penduduk yang tidak mencari pekerjaan karena sudah diterima bekerja tetapi belum mulai bekerja. Menurut Sukirno (1994), pengangguran adalah suatu keadaan dimana seseorang 
yang termasuk dalam angkatan kerja ingin memperoleh pekerjaan akan tetapi belum mendapatkannya. Seseorang yang tidak bekerja namun tidak secara aktif mencari pekerjaan tidak tergolong sebagai pengangguran. Faktor utama yang menyebabkan terjadinya pengangguran adalah kurangnya pengeluaran agregat. Pengusaha memproduksi barang dan jasa dengan maksud memperoleh keuntungan, akan tetapi keuntungan tersebut akan diperoleh apabila pengusaha tersebut dapat menjual barang dan jasa yang mereka produksi. Semakin besar permintaan, semakin besar pula barang dan jasa yang mereka wujudkan. Kenaikan produksi yang dilakukan akan menambah penggunaan tenaga kerja.

\section{$\underline{\text { Tinjauan Empiris }}$}

Pada bagian ini memuat tentang penelitian-penelitian yang telah dilakukan sebelumnya sebagai studi empiris yang mendasari pemikiran penulis dan menjadi pertimbangan dalam penyusunan skripsi ini, antara lainsebagai berikut:

1. Vika Novi Yanti (2011). Dengan judul Analisis FaktorFaktor yang Mempengaruhi Tingkat Pengangguran di Jawa Tengah.

Dengan menggunakan metode metode deskriktif kuantitatif, dari hasi penelitian bahwa Dari hasil estimasi variabel PDRB, Inflasi, Investasi dan Upah Minimu memiliki pengaruh yang signifikan terhadap variabel Pengangguran pada tingkat signifikasi $1 \%$. Sedangkan hanya variabel pertumbuhan penduduk yang tidak memiliki pengaruh signifikan terhadap pengangguran pada tingkat signifikasi sampai dengan $10 \%$.

2. Irfan Payoh (2014). Dengan judul Analisis Faktor-Faktor yang Mempengaruhi Tingkat Pengangguran di Provinsi Sulawesi Utara. Dengan menggunakan metode deskriktif kuantitatif. Hasil penelitian di mana berdasarkan hasil Uji $\mathrm{F}$ penelitian dan pengujian data yang telah dilakukan dari ketiga faktor yakni tingkat upah, inflasi dan pertumbuhan PDRB, berpengaruh signifikan terhadap tingkat pengangguran di Provinsi Sulawesi Utara sedangkan hasil Uji t Upah berpengaruh signifikan, sedangkan tingkat inflasi dan pertumbuhan PDRB tidak berpengaruh signifikan terhadap tingkat pengangguran di Provinsi Sulawesi Utara.

3. Mangaradot Saura A. Sinaga dengan judul Analisis FaktorFaktor yang Mempengaruhi Tingkat Pengangguran di Sumatera Utara. Dengan menggunakan metode deskriktif kuantitatif. Hasil penelitian Uji t bahwa Inflasi dan PDRB tidak berpengaruh secara signifikan terhadap tingkat Pengangguran di Sumatera Utara Sedangkan, Dari hasil pengolahan data diperoleh hasil uji $F$ tingkat inflasi dan PDRB secara bersama-sama 


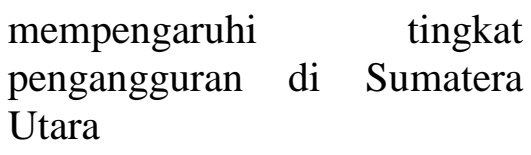

$\underline{\text { Definisi Konsep }}$

Adapun definisi konsepsional
untuk mempermudahkan dan
memberikan gambaran yang lebih
jelas mengenai semua variabel yang
akan diukur dalam penelitian, penulis
menguraikan definisi konsepsional
sebagai berikut:

1. Upah Minimum Regional dan Kota (UMR/UMK) Upah minimum sebagaimana yang telah diatur dalam Undangundang

Ketenagakerjaan No. 8/1981 merupakan upah yang ditetapkan secara Minimum Regional, Sektoral Regional, maupun Subsektoral. Dalam hal ini upah minimum itu adalah upah pokok dan tunjangan (Sumarsono, 2009).

2. Inflasi Inflasi adalah kecenderungan dari hargaharga untuk menaik secara menyeluruh dan terus menerus. Kenaikan harga dari satu atau dua barang saja tidak disebut inflasi, kecuali bila kenaikan tersebut meluas atau mengakibatkan kenaikan pada sebagian besar harga barangbarang lain yaitu harga makanan, minuman, rokok, dan tembakau, harga sandang, harga kesehatan, harga pendidikan, rekreasi, dan olahraga, harga transportasi, komunikasi, dan jasa keuangan (Boediono, 1999).

3. Pertumbuhan Ekonomi Menurut Boediono, pertumbuhan ekonomi adalah proses kenaikan output perkapita dalam jangka panjang. Jadi, persentase pertambahan output itu haruslah lebih tinggi dari presentase perambahan jumlah penduduk dan ada kecendrungan dalam jangka panjang bahwa pertumbuhan itu akan berlanjut. Menurut model pertumbuhan ekonomi HarrodDomar tentang teori pertumbuhan mantap (Steady Growth Theory) yang merupakan pengembangan analisis keynes, lebih menekankan pada peranan kunci perlunya penanaman modal dalam proses penciptaan pertumbuhan ekonomi (Tarigan, 2009).

4. Pertumbuhan penduduk Pertumbuhan penduduk adalah perubahan jumlah penduduk di suatu wilayah tertentu pada waktu tertentu dibandingkan waktu sebelumnya. Semakin maraknya pertumbuhan penduduk di suatu wilayah maka akan semakin banyak pula masyarakat yang menganggur atau yang tidak mempunyai pekerjaan karena lapangan kerja yang tercipta tidak memenuhi syarat untuk jumlah penduduk yang semakin bertambah tiap tahunnya (Sadono Sukirno , 2005). 5. Pengangguran Pengangguran adalah penduduk yang tidak bekerja namun sedang mencari pekerjaan atau sedang mempersiapkan suatu usaha 
baru atau penduduk yang tidak mencari pekerjaan karena sudah diterima bekerja tetapi belum mulai bekerja (Badan Pusat Statistik).

\section{METODOLOGI PENELITIAN}

\section{Desain Penelitan}

Penelitian ini menggunakan metode kuantitatif, karena metode yang digunakan berkaitan dengan pengumpulan, pengolahan dan penyajian data menjadi informasi lebih mudah untuk diinterpretasikan mengenai tingkat pengangguran di Kota Tarakan secara parsial dan simultan. Dimana penulis akan menggambarkan pengaruh upah, inflasi, pertumbuhan ekonomi dan pertumbuhan penduduk apakah dapat mempengaruhi besar kecilnya tingkat pengangguran di Kota Tarakan secara parsial dan simultan. Untuk membuktikan hipotesis, penulis menggunakan metode yang menganalisis data dengan menggunakan model matematik dan statistik yaitu analisis regresi linier berganda.

\section{Objek, Lokasi, waktu penelitian}

Objek dan lokasi penelitian ini dilakukan di Kota Tarakan. Adapun pemilihan wilayah tersebut karena penulis melihat bahwa jumlah penduduk di Kota Tarakan yang meningkat dari tahun ke tahun dan tingkat pengangguran Kota Tarakan adalah berada di urutan pertama di Provinsi Kalimantan Utara dengan jumlah 5.841 jiwa. Sedangkan waktu penelitian ini dilakukan dengan memproleh data dari instansi pemerintahan Badan Pusat Statistik
Kota Tarakan dan Dinas Ketenagakerjaan dan Perindustrian Kota Tarakan. Dengan estimasi pengambilan data yang dilakukan dari tahun 2007-2016.

Metode Analisis Data

Uji Asumsi Klasik

1. Uji Normalitas Menurut Ghozali (2011) uji normalitas bertujuan untuk menguji apakah dalam model regresi, variabel penggangu atau residual memiliki distribusi normal.

2. Uji multikolinearitas bertujuan untuk menguji apakah model regresi ditemukan adanya korelasi antar variabel bebas (independen). Model regresi yang baik seharusnya tidak terjadi korelasi di antara variabel independen (Ghozali, 2011).

3. Uji heteroskedastisitas bertujuan untuk menguji apakah dalam model regresi terjadi ketidak samaan varian dari residual satu pengamatan ke pengamatan lainnya.

4. Uji ini digunakan untuk melihat apakah spsesifikasi model yang digunakan sudah benar atau tidak. Apakah fungsi yang digunakan dalam suatu studi empiris sebaiknya berbentuk linier, kuadrat atau kubik. Dengan uji linieritas akan diperoleh informas apakah model empiris sebaiknya linier, kuadrat, atau kubik (Ghozali, 2011).

\section{$\underline{\text { Uji Statistik }}$}

1. Analisis deskriptif adalah untuk membuat deskripsi gambaran atau lukisan secara sistematis, 
faktual dan akurat mengenai data yang dilihat dari rata-rata (mean), standar diviasi, maksimum dan minimum (Ghozali, 2011).

2. Uji Regresi Linear Berganda. Setelah melalui uji asumsi klasik, yang meliputi uji normalitas,uji multikolinearitas, uji heteroskedastisitas, dan uji linieritasserta data telah terdistribusi normal, maka data yang sudah dikumpulkan tersebut dianalisa dengan menggunakan metode regresi linier berganda dengan bantuan program Statistical. Analisis regresi adalah studi mengenai ketergantungan variabel dependen dengan satu atau lebih variabel independen untuk memprediksi nilai rata-rata populasi atau nilai rata-rata variabeldependen berdasarakan nilai variabel independen yang diketahui.

3. Uji R2 Menurut Widarjono (2005) uji $\mathrm{R}^{2}$ digunakan untuk mengukur persentase variabel terikat yang dijelaskan oleh semuah variabel bebasnya. Nilai koefisien determinasi terletak antara 0 dan 1 ( $0<\mathrm{R}^{2}<$ 1 ), dimana semakin besar nilai $\mathrm{R}^{2}$ suatu regresi atau semakin mendekati 1, maka akan semakin tepat suatu garis regresi.

Pengujian Hipotesis

Uji t (Parsial)

Uji $\mathrm{t}$ berarti melakukan pengujian terhadap koefisien regresi secara parsial. Pengujian ini dilakukan untuk mengetahui signifikansi peran secara parsial antara variabel independen terhadap variabel dependen dengan mengasumsikan bahwa variabel independen lain dianggap konstan.

\section{$\underline{\text { Uji F (Simultan) }}$}

Uji $F$ adalah pengujian terhadap koefisien regresi secara simultan. Pengujian ini dilakukan untuk mengetahui pengaruh semua variabel independen yang terdapat di dalam model secara bersama-sama (simultan) terhadap variabel dependen.

\section{HASIL PENELITIAN}

\section{Gambaran Umum Kota Tarakan}

Tarakan menurut cerita rakyat berasal dari Bahasa Tidung, yang artinya tempat singgah tarak dan makan ngakan yang secara harfiah dapat diartikan: tempat para nelayan untuk istirahat makan, bertemu serta melakukan barter hasil tangkapan dengan nelayan lain. Sesuai dengan namanya pulau ini berfungsi sebagai tempat persinggahan atau tempat istirahat dan melakukan barter kaum nelayan dari Kerajaan Tidung pada masa sebelum datangnya kaum Kolonial Belanda (BPS Kota Tarakan, 2017).

\section{Hasil Pengujian Statistik}

Analisis Deskriktif

Berdasarkan analisi diksripsi hasil perhitungan bahwa rata-rata (mean) pengangguran sebesar 8,626. Sedangkan standar deviasi untuk penganguran adalah sebesar 2.597. Upah memiliki nilai rata-rata (mean) upah sebesar 14,158. Sedangkan 
standar deviasi untuk upah adalah sebesar 0,477. Inflasi memiliki nilai rata-rata (mean) sebesar 8,416. Sedangkan standar deviasi untuk Inflasi adalah sebesar 4,746. Perumbuhn ekonomi memiliki nilai rata-rata (mean) sebesar 7,385. Sedangkan standar deviasi untuk pertumbuhan ekonomi adalah sebesar 2,148. Pertumbuhan penduduk memiliki nilai rata-rata (mean) sebesar 3.564. Sedangkan standar deviasi untuk pertumbuhan penduduk adalah sebesar 6.515. dari keempat variabel di atas dapat di simpulkan bahwa variabel di atas mengindikasikan hasil yang baik karena standar deviasi lebih kecil dari nilai rataratanya (mean), sehingga simpangan data pada variabel keempat variabeln ini dapat dikatakan baik.

\section{$\underline{\text { Analisis Regresi Linear Barganda }}$}

Persamaan regresi linear berganda adalah sebagai berikut: $\mathrm{Y}=\beta 0+\beta 1 \mathrm{LnX} 1+\beta 2 \mathrm{X} 2+\beta 3 \mathrm{X} 3+$ B4X4+e $\quad \mathrm{Y}=80,689$ 4,968X1+0,033X2-0,216X3

$0,116 \mathrm{X} 4$ + e maka hasil regresi linear berganda dapat disimpulkan sebagai berikut:

a. Konstanta sebesar 80,689 Jika semua variabel independen upah, inflasi, pertumbuhan ekonomi, dan pertumbuhan penduduk nilainya 0 , maka besarnya tingkat pengangguran mempunya nilai sebesar 80,689 persen

b. Koefisien regresi upah sebesar 4,968 menyatakan bahwa setiap kenaikan 1 rupiah upah akan menurunkan tingkat pengangguran sebesar 4,968 persen dalam hal ini faktor lain dianggap konstan.

c. Koefisien regresi inflasi sebesar 0,033 menyatakan bahwa setiap kenaikan 1 persen inflasi akan menaikan tingkat pengangguran sebesar 0,033 persen dalam hal ini faktor lain dianggap konstan.

d. Koefisien regresi pertumbuhan ekonomi sebesar $-0,216$ menyatakan bahwa setiap kenaikan 1 persen pertumbuhan ekonomi akan menurunkan tingkat pengangguran sebesar 0,216 persen dalam hal ini faktor lain dianggap konstan.

e. Koefisien regresi Pertumbuhan Penduduk sebesar $\quad-0,116$ menyatakan bahwa setiap kenaikan 1 persen pertumbuhan penduduk akan menurunkan tingkat pengangguran sebesar 0,116 persen dalam hal ini faktor lain dianggap konstan.

\section{$\underline{\text { Hasil uji-F Simultan }}$}

Hasil uji statistik F upah, inflasi, pertumbuhan ekonomi dan pertumbuhan penduduk terhadap tingkat pengangguran di dapatkan nilai $F$ hitung $=20,205$ dengan tingkat signifikan 0,05 dan $\mathrm{F}$ tabel sebesar F 0,05 (4)(5) = 5,192 dengan nilai signifikan yang dipersyaratkan 0,05 . Artinya variabel upah, inflasi, pertumbuhan ekonomi dan pertumbuhan penduduk secara simultan berpengaruh signifikan terhadap tingkat pengangguran karena nilai $\mathrm{F}$ hitung $>\mathrm{F}$ tabel $(20,205>5,192)$. 


\section{$\underline{\text { Hasil uji-t Parsial }}$}

Hasil dari perhitungan uji-t signifikansi pengaruh dari masingmasing variabel bebas terhadap variabel terikat adalah sebagai berikut :

a. Berdasarkan hasil uji statistik $t$ dari tabel diatas, upah (X1) terhadap tingkat Pengangguran (Y) didapatkan nilai $\mathrm{t}$ hitung $=$ 7,701 dan t-tabel $=2,570$ yang didapat dari tabel dengan rumus $\mathrm{df}=\mathrm{n}-\mathrm{k}-1=10-4-1=5$, dengan nilai signifikan yang dipersyaratkan 0,05. Maka dapat disimpulkan bahwa variabel upahsecara parsial berpengaruh signifikan terhadap tingkat pengangguran di Kota Tarakan karena nilai t-hitung > t-tabel $(7,701>2,570)$.

b. Berdasarkan hasil uji statistik $\mathrm{t}$ dari tabel diatas, inflasi (X2) terhadap tingkat pengangguran (Y) didapatkan nilai t-hitung $=$ 0,440 dan $\mathrm{t}$-tabel $=2,570$ yang didapat dari tabel dengan rumus $\mathrm{df}=\mathrm{n}-\mathrm{k}-1=10-4-1=5$, dengan nilai signifikan yang dipersyaratkan 0,05. Maka dapat disimpulkan bahwa variabel Inflasi secara parsial tidak berpengaruh signifikan terhadap tingkat pengangguran di Kota Tarakan karena nilai t-hitung< ttabel $(0,440<2,570)$.

c. Berdasarkan hasil uji statistik $\mathrm{t}$ dari tabel diatas, pertumbuhan ekonomi (X3) terhadap tingkat pengangguran (Y) didapatkan nilai t-hitung $=1,524$ dan $\mathrm{t}$ tabel $=2,570$ yang didapat dari tabel dengan rumus $\mathrm{df}=\mathrm{n}-\mathrm{k}-1=10-$ $4-1=5$, dengan nilai signifikan yang dipersyaratkan 0,05. Maka dapat disimpulkan bahwa variabel pertumbuhan ekonomi secara parsial tidak berpengaruh signifikan terhadap tingkat pengangguran di Kota Tarakan karena nilai t-hitung < t-tabel $(1,524<2,570)$.

d. Berdasarkan hasil uji statistik $t$ dari tabel diatas, pertumbuhan penduduk (X4) terhadap tingkat pengangguran (Y) didapatkan nilai t-hitung $=2,139$ dan $\mathrm{t}$-tabel $=$ 2,570 yang didapat dari tabel dengan rumus $\mathrm{df}=\mathrm{n}-\mathrm{k}-1=10$ $4-1=5$, dengan nilai signifikan yang dipersyaratkan 0,05. Maka dapat disimpulkan bahwa variabel pertumbuhan penduduk secara parsial tidak berpengaruh signifikan terhadap tingkat pengangguran di Kota Tarakan karena nilai t-hitung < t-tabel $\underline{(2,139<2,570)}$.

\section{$\underline{\text { Koefesien Determinasi (R2) }}$}

koefisien determinasi atau $\mathrm{R}$ Square sebesar 0,942. ini berarti bahwa 94,2 \% variabel Tingkat Pengagguran dapat dijelaskan oleh variasi keempat variabel independen yaitu upah (X1), inflasi (X2), pertumbuhan ekonomi (X3) dan pertumbuhan penduduk (X4) sisanya $5,8 \%$ dijelaskan oleh variabel lain yang tidak dimasukkan dalam model penelitian ini.

Pembahasan

\section{Uji Hipotesis Pertama}

Berdasarkan hasil uji statistik F dari tabel diatas, upah, inflasi, pertumbuhan ekonomi dan pertumbuhan penduduk secara simultan berpengaruh signifikan 
terhadap tingkat pengangguran didapatkkan nilai F-hitung $=20,205$ dengan tingkat signifikan 0,05 dan Ftabel sebesar $=5,192$ dengan nilai signifikan yang dipersyaratkan 0,05. Artinya variabel upah, inflas, pertumbuhan ekonomi dan pertumbuhan penduduk secara simultan berpengaruh signifikan terhadap tingkat pengangguran karena nilai F-hitung> F-tabel $(20,205>5,192)$.

\section{Uji Hipotesis kedua}

Upah berpengaruh signifikan terhadap tingkat pengangguran yang ditunjukkan pada pengujian didapatkan nilai t-hitung sebesar 7,701 dan nilai t-tabel pada taraf nyata $5 \%$ sebesar 2,570. Berdasarkan nilai t-hitung 7,701 > t-tabel 2,570 maka Ho ditolak dan $\mathrm{Ha}$ diterima dengan nilai koefisien upah sebesar 4,968 menyatakan bahwa setiap kenaikan 1 rupiah upah akan menurunkan tingkat pengangguran sebesar 4,968 persen. Dari hasil diatas, menunjukkan bahwa upah mempunyai hubungan yang negatif dan berpengaruh signifikan terhadap pengangguran di Kota Tarakan. Dalam hal ini, berlawanan dengan hipotesis dan landasan teori yang ada dalam penelitian ini, yakni yang menyatakan ada hubungan yang positif antara upah minimum dengan tingkat pengangguran dimana, jika terjadi kenaikan upah minimum maka akan diikuti dengan kenaikan tingkat pengangguran yang disebabkan oleh pengurangan tenaga kerja yang akan diterapkan oleh perusahaan saat terjadi kenaikan upah minimum disetiap tahunnya. Hasil yang diperoleh dalam penelitian ini sama dengan penelitian terdahulu oleh, Nirmala Mansur yakni hasilnya ada hubungan yang negatif antara kenaikan upah minimum dengan tingkat pengangguran. Dari hasil yang diperoleh, yakni ketika terjadi kenaikan upah minimum di Provinsi Sulawesi Utara dari tahun ke tahun ini ternyata juga akan mendukung bahwa pengangguran akan berkurang dengan kenaikan upah minimum dari tahun ke tahun tersebut. Keadaan ini bisa terjadi, dikarenakan ada beberapa kemungkinan diantaranya, diduga titik kenaikan upah ini berada dibawah titik keseimbangan, kemudian apabila di Kota Tarakan upah semakin meningkat, ini diduga akan mendorong serta merangsang para penganggur untuk segera mencari pekerjaan sehingga dapat mengurangi jumlah pengangguran di Kota Tarakan. Hal ini tentunya dengan catatan diharapkan lebih memperbanyak pelatihan untuk dapat mengasah keahlian-keahlian dalam dunia kerja sehingga perusahaan dapat memberikan ruang bagi pekerja karena tentunya pelaku bisnis membutuhkan tenaga profesional untuk menjalankan dan mengembangkan perusahaan. Inflasi tidak berpengaruh signifikan terhadap tingkat pengangguran yang ditunjukkan pada pengujian didapatkan nilai t-tabel pada taraf nyata $5 \%$ sebesar 2,570 . Berdasarkan nilai t-hitung $0,440<$ ttabel 2,570 maka Ho diterima dan Ha ditolak dengan nilai koefisien regresi inflasi sebesar 0,033. Hasil ini tidak sesuai dengan teori kurva philips menyimpulkan adanya hubungan timbal balik antara tingkat pengangguran dan laju inflasi, yaitu 
apabila pemerintah ingin menetapkan tingkat pengangguran yang rendah, maka ini hanya akan dapat dicapai dengan tingkat inflasi yang tinggi, dan begitu sebaliknya. Inflasi berpengaruh positif di karenakan terjadi kenaikan harga-harga secara umum di Kota Tarakan maka otomatis ongkos produksipun juga akan naik sehingga kegiatan produksi dinilai kurang produktif, efek ini akan berpengaruh terhadap tingkat pengangguran karena kesempatan kerja yang akan dibatasi. Berdasarkan penelitian terdahulu, penelitian ini sesuai dengan penelitian Irfan Payoh yang mengatakan Inflasi tidak berpengaruh signifikan terhadap tingkat pengagguran di Provinsi Sulawesi Utara.

Pertumbuhan ekonomi tidak berpengaruh signifikan terhadap tingkat pengangguran yang ditunjukkan pada pengujian didapatkan nilai t-hitung sebesar 1,524 dan nilai t-tabel pada taraf nyata $5 \%$ sebesar 2,570. Berdasarkan nilai t-hitung $1,524<\mathrm{t}$-tabel 2,570 maka Ho diterima dan $\mathrm{Ha}$ ditolak dengan nilai koefisien regresi pertumbuhan ekonomi sebesar 0,216. Hal ini dikarenakan pertumbuhan ekonomi yang ada di Kota Tarakan dalam beberapa tahun terakhir memang mengalami peningkatan yang relatif baik dan hal ini merupakan cerminan dari pertumbuhan sektor yang ada di Kota Tarakan, namun pertumbuhan ekonomi yang relatif meningkat dalam setiap periode juga belum dapat memberikan mengenai kejelasan dalam pengurangan jumlah pengangguran yang ada di Kota Tarakan, pertumbuhan ekonomi yang ada memang mengalami peningkatan namun dalam hal ini, jumlah pengangguran atau tingkat pengangguran yang ada tidaklah sebanding dengan tingkat pertumbuhan ekonomi di Kota Tarakan. Hal ini dikarenakan pertumbuhan ekonomi tidak dibarengi oleh peningkatan kapasitas produksi, sehingga tingkat pengangguran tetap meningkat seiring dengan pertumbuhan ekonomi. Berdasarkan penelitian terdahulu, penelitian ini sesuai dengan penelitian Riza Firdhania yang mengatakan pertumbuhan ekonomi tidak berpengaruh signifikan terhadap tingkat pengagguran di Kabupaten Jember.

Pertumbuhan penduduk tidak berpengaruh signifikan terhadap tingkat pengangguran yang ditunjukkan pada pengujian didapatkan nilai t-hitung sebesar 2,139 dan nilai t-tabel pada taraf nyata $5 \%$ sebesar 2,570 . Berdasarkan nilai t-hitung 2,139 < t-tabel 2,570 maka Ho diterima dan Ha ditolak dengan nilai koefisien regresi pertumbuhan penduduk sebesar $-0,116$. Hasil ini tidak sesuai dengan teori yang ada yang menyatakan bahwa semakin besarnya pertumbuhan penduduk di suatu wilayah maka akan semakin banyak pula masyarakat yang menganggur atau yang tidak mempunyai pekerjaan karena lapangan kerja yang tercipta tidak memenuhi syarat untuk jumlah penduduk yang semakin bertambah tiap tahunnya. Hal ini dikarenakan pertumbuhan penduduk di Kota Tarakan dalam setiap periodenya memang mengalami peningkatan namun pertumbuhan penduduk yang 
meningkat itu tidak mempengaruhi besarnya tingkat pengangguran yang ada di Kota Tarakan, karena jumlah lapangan pekerjaan dan kesempatan kerja yang ada di Kota Tarakan dapat mengimbangi dari besarnya pertumbuhan penduduk yang ada sehingga, walaupun pertumbuhan penduduk meningkat tidak akan mempengaruhi tingkat pengangguran yang ada di Kota Tarakan.

Selain itu dari segi penduduk itu sendiri bahwa penduduk memiliki dua peranan dalam pembangunan ekonomi salah satunya dari segi permintaan dan yang lain dari segi penawaran. Dari segi permintaan penduduk bertindak sebagai konsumen dan dari segi penawaran penduduk bertindak sebagai produsen. Oleh karena itu, perkembangan penduduk yang cepat tidaklah selalu berpengaruh terhadap tingkat pengangguran, jika penduduk ini mempunyai kapasitas tinggi untuk menghasilkan dan menyerap hasil produksi yang dihasilkan, ini berarti tingkat pertambahan penduduk yang tinggi disertai dengan tingkat penghasilan yang tinggi pula akan berdampak baik bagi daerah tersebut terutamanya di Kota Tarakan.

\section{KESIMPULAN}

Secara Simultan. Berdasarkan hasil penelitian dan pengujian data yang telah di lakukan maka dapat disimpulkan, dari keempat varibel (X) yakni, upah, inflasi, pertumbuhan ekonomi dan pertumbuhan penduduk. berpengaruh signifikan terhadap tingkat pengagguran di Kota Tarakan.

Secara Parsial. Berdasarkan hasil penelitian dan pengujian data yang telah di lakukan maka dapat disimpulkan, dari keempat varibel (X) yakni, Variabel X1 upah berpengaruh signifikan terhadap tingkat pangagguran di Kota Tarakan. Sedangkan variabel X2 inflasi tidak berpengaruh signifikan terhadap tingkat pengangguran di Kota Tarakan. Sedangkan variabel X3 pertumbuhan ekonomi tidak berpengaruh signifikan terhadap tingkat pengangguran di Kota Tarakan dan variabel X4 pertumbuhan penduduk tidak berpengaruh signifikan terhadap tingkat pengangguran di Kota Tarakan.

\section{SARAN}

Upah memiliki pangaruh yang signifikan terhadapa tingkat pengangguran di Kota Tarakan, yakni memiliki hubungan negatif. Dengan adanya peningkatan upah terhadap penurunan pengagguran, tentunya harus diikuti dengan kualitas pekerja itu sendiri. Peningkatan kualitas pekerja disini lebih menitik beratkan kepada pemerintah daerah yang diharapkan dapat lebih banyak lagi memberikan pelatihan-pelatihan gratis bagi tenaga kerja yang ada di Kota Tarakan, salah satunya melalui pembentukan pusat-pusat pelatihan khusus bagi pekerja, ini tentunya agar dapat menciptakan SDM yang baik dan berkualitas di Kota Tarakan dan mampu berdaya saing.

Untuk penelitain selanjutnya, diharapkan agar menambah lebih banyak data dan variabel-variabel lain yang diduga berpengaruh terhadap tingkat pengangguran. 


\section{DAFTAR PUSTAKA}

Agus, Widarjono. 2005. Ekonometrika Teori dan Aplikasinya. Edisi Pertama. Ekonisia. Yogyakarta.

BPS, Kota Tarakan Dalam Angka 2017 Data Tingkat Pengangguran, Inflasi, Pertumbuhan Ekonomi dan Pertumbuhan Penduduk. Badan Pusat Statistik.

Dinas Ketenagakerjaan Dan Perindustrian Kota Tarakan 2017 Data Tingkat Upah Kota Tarakan.

Firdhania, Riza, 2017. Faktor-faktor yang mempengaruhi tingkat pengangguran di Kabupaten Jember. Jurnal Ekonomi Bisnis dan Akuntansi,2017 Vol IV (1) : 112-121.

Ghozali, Imam. 2011. Aplikasi Analisa Multivariate. Edisi Cetakan V. Penerbitan Badan Universitas Diponegoro. Semarang.

M, Robinson, Taringan. 2009. Ekonomi Regional Teori Dan Aplikasi Edisi Revisi Cetakan Kelima. Penerbitan PT. Bumi Aksara. Jakarta.

Mankiw, N. G. (2012). Makroekonomi. Jakarta: Erlangga.

Michael, Todaro.(2000). Pembangunan ekonomi di dunia ketiga edisi ketujuh terjemahan haris munandar. Erlangga. Jakarta

Mulyadi, S. 2003. Ekonomi Sumber Daya Manusia Dalam Perspektif Pembangunan. Edisi Revisi Cetakan Kedua. Penerbitan PT. Raja Grafindo Persada. Jakarta.
Rusli, Said. 1995. Pengantar Ilmu Kependudukan. Edisi Revisi Cetakan ketujuh. Penerbitatan PT. Pustaka LP3ES Indonesia. Jakarta.

Sadono Sukirno, Pengantar Teori Ekonomi Makro (Jakarta : PT.Raja Grafindo Persada, 2005).

Sonny, Sumarsono. 2009. Teori dan Kebijakan Publik Ekonomi Sumber Daya Manusia. Edisi Pertama Cetakan Pertama. Penerbitan Graha Ilmu Candi Gerbang Permai. Yogyakarta.

Sugiyono dan Eri, Wibowo. 2004. Statistika Untuk Penelitian. Penerbitan ALFABETA. Bandung.

Sukirno, $\quad 2010$. Makroekonomi: Teori Pengantar. Edisi 3. Jakarta: Rajawali Pers. 